Relations industrielles

Industrial Relations

\title{
A Courageous and Successful Venture
}

\section{Justin}

Volume 5, numéro 3, décembre 1949

URI : https://id.erudit.org/iderudit/1023300ar

DOI : https://doi.org/10.7202/1023300ar

Aller au sommaire du numéro

\section{Éditeur(s)}

Département des relations industrielles de l’Université Laval

\section{ISSN}

0034-379X (imprimé)

1703-8138 (numérique)

Découvrir la revue

Citer cet article

Justin (1949). A Courageous and Successful Venture. Relations industrielles / Industrial Relations, 5(3), 25-26. https://doi.org/10.7202/1023300ar

Tous droits réservés @ Département des relations industrielles de l’Université Laval, 1949
Ce document est protégé par la loi sur le droit d'auteur. L’utilisation des services d'Érudit (y compris la reproduction) est assujettie à sa politique d'utilisation que vous pouvez consulter en ligne.

https://apropos.erudit.org/fr/usagers/politique-dutilisation/ 


\section{A COURAGEOUS AND SUCCESSFUL VENTURE}

Brother JUSTIN, F.S.C.

On November 21 and 22, the Faculty of Social Sciences of Laval University sponsored a Roundtable Conference on «The Church and Economic Changes» for the English speaking employers of the province of Quebec. The charming Kent House on the rim of Montmorency Falls was scene of this most unusual venture. As attendance was by invitation only some eighty odd representatives of the most important industries in the province were present. The panel of discussion leaders was composed of Rev. Paul-Emile Bolté, of Montreal University, Mr. Murray G. Ballantyne, editor of «The Ensign », Rev. Gérard Dion, of Laval University and Brother Justin, F.S.C., of Manhattan College, New York City. The two priest-members of the panel are members of the Sacerdotal Commission of Social Studies.

The meetings were held each day from ten to noon and from two to four o'clock. In developing the theme of the Conference these topics were discussed: "The Church and Property»; «The Church and Enterprise»; «The Church and The Right to Organize» and «Priests and Economics ». Each discussion leader was asked to speak informally on his topic for twenty minutes and then the floor was thrown open for questions.

The industrial scene in the province of Quebec is unique in this part of the world. About eighty five percent of the work force is loyally Catholic and acutely aware of the social teachings of the Church. About the same percentage of management is non-Catholic and, in general, not familiar with these social teachings. The purpose of the Conference was to bring representatives of this important non-Catholic group of industrialists together with some teachers of the Catholic social doctrine to give these members of management an opportunity to learn the basic tenets of this social teaching or to clear away doubts and misunderstandings. So that all concerned might talk freely and frankly no records of the proceedings were made and the press was not invited.
The steps taken by the organizer of the Conference to keep it a small group, meeting privately and without the glare of publicity, brought about a most pleasant and seemingly a very beneficial meeting. The Conference members had every chance to explain their difficulties and to seek answers in an atmosphere which was characterized by an academic detachment which was very refreshing. The absence of the press kept the discussions free and unstilted by fear of incorrect or incomplete quotations. Finally the two hour luncheon period allowed all to engage in a yet more informal exchange of ideas.

The Conference represented a sizable investment of time, energy and money. What aid it accomplish and were its accomplishments worthy of this investment? Frankly, there are no exact answers to those two very natural questions. The Conference was conceived as an opportunity to give English speaking management of the province an opportunity to have the social teachings of the Church explained to them. It is agreed that whether management wishes it or not, in the province of Quebec, it has to face the problems which will arise because of the social teachings of the Church. To prepare management for this task eight conference hours was a very short time and most of the people who gathered at Kent House regretfully agreed with this judgment. Our busy work world, however, cannot spend its life in the lecture halls so that it seems that conferences such as this will have to be the accepted medium of communication in this area of life.

There was no doubt in the minds of all present that the Conference did much to achieve the end for which it had been convoked. The question periods cleared up doubts and misapprehensions but in the long run it well may be that the outstanding accomplishment of the conference was the fact it was held. Just to hold this meeting was a frank admission by all that tensions and misunderstandings existed and that the realities must be faced if peace and prosperity are to be preserved. That may be the reason why everyone who spoke privately to the author at the close 
of the proceedings paid tribute to the vision and the courage of Father Dion for having organized and directed this Roundtable.

Future conferences should be very successful. The pattern has been set, a mood has been created and an objective has been clearly defined. To a stranger from south of the border, it appeared that on those two November days the Kent House harbored too many men of intelligence and good will for anything but a most successful future.

\section{THE FIFTH A. P. I. CONVENTION \\ Gaston Cholette}

The Association professionnelle des industriels held a brilliant convention in Quebec City the fourteenth and fifteenth of November. The setting was excellent and the prestige and worth of the speakers added to the conspicuous success of the meetings.

The organizers had thought it opportune to single out the May seventh address of His Holiness, Pius XII for the consideration of the members with the following title as the central theme «The Employer and his Enterprise ».

The first address, bearing on employeremployee co-operation, was delivered by Mr. Gilbert Ayers, of the Ayers Co. Ltd., of Lachute. In the course of his exposition and the discussion which followed, the importance of the advanced social security measures of private initiative with their relatively low cost and their favourable repercussions on the workers especially at times of wage increase demands, was stressed.

At lunch time a substantial bit of philosophy on the rights of ownership was presented by a well-known university professor, Father Louis Lachance, o.p. The speaker brought to light the traditional base of ownership rights in general, the elements justifying private ownership and, above all, the social function of private ownership. The universal satisfaction of human needs is one of the primary requirements of natural law he said, and private ownership is good only in the measure that it constitutes an efficacious means of fulfilling this role. Afterwards, the undersigned asked Father Lachance if certain parts of his speech could be interpreted as expressing a divergence of opinion with some conclusions of the pamphlet of the «Sacerdotal Commission of Social Studies » on «The Sharing of Workers in the Life of the Enterprise ». The learned Dominicain replied that he had read this publication with care and that nothing in his own speech contradicted the thought of the Sacerdotal Commission.

Monday afternoon was marked by two exceedingly interesting addresses - one on industrial organization, the other on reforms of structure in the enterprise. The first was given by Monsieur Marcel Clément and the second by Monsieur François-Albert Angers. The most important conclusion arising from them was the joint proposal of the two speakers to the A.P.I. that they form industrial groups with the mission of instituting a regular, systematic and organic co-operation with the corresponding branches of the workers' syndicates with a view of realizing as efficiently as possible the employer-employee collaboration asked for in the encyclicals and other pontifical texts. This important exhortation, seen in the perspective of the Pope's address of May seventh and in its relation with the later speeches of Monsieur Vittorio Vaccari and Monseigneur Roy, constitutes one of the best resolutions which could have been formulated on this occasion by an employers' association of Catholic inspiration.

The first day came to a close with the address of Monsieur Vittorio Vaccari, general-secretary of the «Association des employeurs catholiques de Belgique», and the speech of His Excellence Monseigneur Maurice Roy, Roman Catholic Archbishop of Quebec. Monsieur Vaccari had been invited to speak of the social directives of Pius XII and particularly to interprete his discourse of May seventh to employers. Here are some important extracts from his text. "One should interprete it (this discourse of Pius XII) in the framework of the social directives which, beginning with Rerum Novarum, the Papacy has never ceased giving the peoples of the earth... There are some who have incorrectly discovered in this address a change of direction with regard to the principles enunciated in the other documents... And it is necessary to state that in certain circles there are employers who, having given only a superficial and partial examination, have mutilated the organic construction of the speech in such a fashion as to interpret it as an exposition of the natural rights of the employer rather than also and equally an exposition of his obligations. » A little further on 